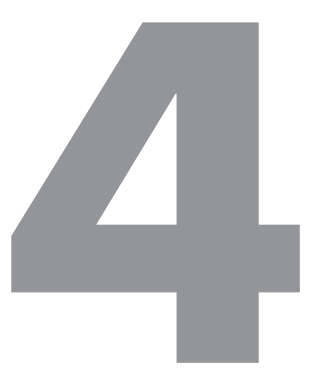

\title{
NATUREZA JURÍDICA DA AÇÃO RESCISÓRIA
}

A natureza jurídica da ação rescisória é de ação autônoma de impugnação de decisão judicial materialmente transitada em julgado. Tem natureza de ação de conhecimento. Não se trata de modalidade recursal. ${ }^{1}$

Tal impugnação comporta, em regra, dois pedidos: rescindente (judicium rescindens) e rescisório (judicium rescisorium). Pela procedência do juízo rescindente, faz-se a desconstituição do julgado, tendo natureza jurídica constitutiva negativa. ${ }^{2}$ Com a procedência do juízo rescisório, o magistrado, por sua vez, rejulga a causa, sendo que tal rejulgamento pode ter um leque ampliado em face das possibilidades da causa de origem. Assim, o juízo rescisório pode assumir natureza constitutiva, condenatória ou meramente declaratória, dependendo do objeto do rejulgamento formulado pelo autor. Saliente-se que tal rejulgamento pode ser total ou parcial; neste último caso, quando o autor apenas pretender o rejulgamento de parcela do julgado rescindendo. ${ }^{3}$

1 MOREIRA, José Carlos Barbosa. Comentários ao Código de Processo Civil, 11. ed., v. V, p. 122.

2 MEDINA, José Miguel Garcia. Novo Código de Processo Civil comentado, p. 1395.

3 AMERICANO, Jorge. Da acção rescisória. 3. ed. São Paulo: Saraiva, 1936. p. 12. 
Consequentemente, com o ajuizamento da ação rescisória forma-se uma relação jurídica processual nova, processo que se distingue daquele anteriormente formado no rescindendo. ${ }^{4}$

Esse entendimento tem base na própria classificação das ações, que segue o conteúdo dos pedidos veiculados. Assim, de acordo com o provimento que constitui o pedido, uma ação poderia ser, antes da edição do atual Código de Processo Civil (porque após ele houve a extinção das chamadas ações autônomas cautelares, passando elas a constituir uma fase antecedente ao pedido principal), de conhecimento, de execução ou cautelar, seguindo o tipo de processo em que é veiculada. ${ }^{5}$ Ao lado dessa teoria trinária ou clássica das ações está a doutrina de Pontes de Miranda, que inclui as ações mandamentais e as executivas lato sensu, definindo a classificação quinária. ${ }^{6}$

Por sua vez, o processo de conhecimento se subdivide em três categorias: processo declaratório (objetiva a certeza do direito), processo condenatório (capaz de impor ao réu prestação de dar, fazer, ou não fazer) e processo constitutivo positivo, negativo ou misto, dependendo se objetiva um provimento jurisdicional para a criação, extinção ou modificação da relação jurídica. As ações constitutivas negativas, que se promovem para extinguir uma relação jurídica já existente, também são chamadas pela doutrina de ações desconstitutivas. ${ }^{7}$

Fato é que, seja como for, todos os processos de conhecimento têm um resquício de natureza declaratória (sentido amplo), sendo que a existência do pedido condenatório ou de pedido que possa alterar a realidade da relação jurídica, ante a alteração da preponderância do pedido em dada ação, definem se a ação tem natureza condenatória ou constitutiva. A inexistência desses pedidos impõe classificar a ação no rol das ações meramente declaratórias. ${ }^{8}$

4 COSTA, Carlos Coqueijo Torreão da. Ação rescisória. 7. ed. rev. e atualizada por Gustavo Lanat Pedreira de Cerqueira. São Paulo: LTr, 2002. p. 32.

5 SÁ, Fernando. As diversas eficácias e seu convívio no conteúdo da sentença - a tese de Pontes de Miranda. Revista da Faculdade de Direito da UFRGS, v. 18, 2000, p. 97.

6 PONTES DE MIRANDA, Francisco Cavalcanti. Tratado das ações. 1. ed. Campinas: Bookseller, 1998. t. I, p. 132.

7 ALVIM, José Eduardo Carreira. Teoria geral do processo. 11. ed. Rio de Janeiro: Forense, 2008. p. 144.

8 "A ação rescisória tem a natureza jurídica de ação constitutiva negativa, que produz, portanto, uma sentença desconstitutiva, quando julgada procedente." (WAMBIER, Teresa Arruda Alvim. Ação rescisória. RePro, São Paulo: RT, n. 40, 1985. p. 136). 
Saliente-se, ainda, que nem toda ação rescisória proposta será procedente. A propositura não induz que haverá desconstituição, podendo a decisão trilhar outros caminhos. Assim, como se pode visualizar sentença procedente, também poderá ser improcedente e parcialmente procedente, comportando juízo rescisório, além da natureza constitutiva negativa (desconstitutiva), que também poderá ser condenatória ou apenas declaratória. ${ }^{9}$

Nesse sentido, em toda ação rescisória, uma vez superada a admissibilidade, faz-se invariavelmente o conhecimento judicial da razão do autor em seu pedido (rescisão de decisão judicial de mérito e eventual rejulgamento). Não há dúvidas de que a ação rescisória, proposta com base no permissivo do art. 966 do CPC/2015, é uma ação de conhecimento. E mais, sobressalta a subcategoria desconstitutiva da sentença de mérito (ou do acórdão) atacada via rescisória e, eventualmente, constitutiva da nova realidade perante o direito regulado no caso concreto. ${ }^{10}$

O novo processo formado a partir da petição inicial rescisória tem natureza jurídica de processo de conhecimento, uma vez que nele será realizada a cognição da tese rescindenda. A sentença produzida na ação rescisória poderá ser constitutiva negativa, no caso de procedência da desconstituição da sentença (juízo rescindente); ainda, poderá trilhar todas as possibilidades de um pronunciamento decisório declaratório, constitutivo, condenatório, mandamental e executivo lato sensu quando do eventual julgamento do pedido rescisório (rejulgamento da causa), ${ }^{11}$ pois, para este, não há limites na cognição, senão no objeto do ajuizamento da demanda originária rescindenda e respectivo petitum rescisorium. No caso de extinção do feito sem julgamento de mérito, a sentença será essencialmente declaratória ou, ainda, na improcedência, então estar-se-á diante de uma sentença declaratória negativa. ${ }^{12}$

9 ALVIM, Eduardo Arruda; Alvim, Angélica Arruda. A ação rescisória e a suspensão da efetivação do julgado rescindendo, à luz da Lei 11.280/2006, p. 995.

10 RODRIGUES, Marcelo Abelha. Elementos de direito processual civil. 3. ed. São Paulo: RT, 2002. v. 1, p. 273.

11 "A sua natureza primordial é desconstitutiva. Isso porque toda ação rescisória tem de ter o juízo rescindente, o pedido de desconstituição total ou parcial do julgamento anterior transitado em julgado. Mas, além dele, quando for o caso, a rescisória poderá ter também o juízo rescisório, em que o tribunal proferirá novo julgamento da questão anteriormente decidida. O juízo rescisório pode ter qualquer tipo de natureza: condenatória, constitutiva ou declaratória. E, sendo condenatória, pode ainda ter natureza mandamental ou executiva lato sensu." (GONÇALVES, Marcus Vinicius Rios. Direito processual civil esquematizado, p. 555).

12 MAGRI, Berenice Soubhie Nogueira. Ação anulatória: art. 486 do CPC, p. 148. 
Em suma, quanto ao objeto, a rescisória caracteriza-se como ação desconstitutiva e, com base no eventual rejulgamento, pode ter também natureza declaratória, constitutiva ou condenatória, conforme o caso. ${ }^{13}$ Não se pode olvidar que a ação rescisória tem natureza jurídica de ação autônoma de impugnação de decisão transitada em julgado. ${ }^{14}$

13 NERY JÚNIOR, Nelson; NERY, Rosa Maria de Andrade. Código de Processo Civil comentado e legislação extravagante. 9. ed. rev., ampl. e atual. São Paulo: RT, 2006. p. 678.

14 CALAMANDREI, Piero. La casación civil. México: Oxford, 2000. p. 187. 